\title{
Fourteen years after the Shahid-Rajaei dam construction: an evaluation of morphometric and genetic differentiation between isolated up- and downstream populations of Capoeta capoeta gracilis (Pisces: Cyprinidae) in the Tajan River of Iran
}

\author{
Hossein AnvariFar ${ }^{1}$, H. Farahmand ${ }^{2}$, D.M. Silva ${ }^{3}$, R.P. Bastos ${ }^{3}$, \\ A. Khyabani ${ }^{1}$ and Hassan AnvariFar ${ }^{4}$ \\ ${ }^{1}$ Department of Fisheries, University of Applied Science and Technology, \\ Golestan, Iran \\ ${ }^{2}$ Department of Fisheries, Faculty of Natural Resources, \\ University of Tehran, Karaj, Iran \\ ${ }^{3}$ Instituto de Ciências Biológicas, Universidade Federal de Goiás, \\ Goiânia, GO, Brasil \\ ${ }^{4}$ Department of Veterinary Science, Faculty of Veterinary Medicine, \\ Islamic Azad University of Babol, Mazandaran, Iran \\ Corresponding author: D.M. Silva \\ E-mail: silvadanielamelo@gmail.com
}

Genet. Mol. Res. 12 (3): 3465-3478 (2013)

Received January 15, 2013

Accepted May 28, 2013

Published September 10, 2013

DOI http://dx.doi.org/10.4238/2013.September.10.3

\begin{abstract}
We evaluated the effects of the Shahid-Rajaei dam, 14 years after its construction, on morphometric and genetic divergence between up- and downstream populations of the Iranian fish SiahMahi (Capoeta capoeta gracilis). Sixty-six specimens were analyzed. There were significant differences between the 2 groups in the means
\end{abstract}


of 16 morphometric characters (univariate analysis). In discriminant function analysis, the proportion of individuals classified into their original groups was 97 and 100\% for up- and downstream populations, respectively. Principal component analysis of morphometric data demonstrated that the up- and downstream samples of Siah-Mahi are clearly distinct. In the genetic analysis, 6 informative primers produced 89 polymorphic bands with $95 \%$ polymorphism. In association analysis between morphological and genetic data, 63 of 89 genetic markers were significantly correlated with the 16 morphometric characters. We conclude that these are 2 morphologically and genetically distinct populations of C. c. gracilis, probably due to limited downstream dispersal and elimination of upstream migration.

Key words: Association analysis; Cyprinid fish; Little black fish; Siah-Mahi

\section{INTRODUCTION}

Many environmental impact reports have shown that construction of a dam can lead to dramatic changes in the environment and can particularly affect the diversity of fish communities (Craig, 2000; Haas et al. 2010). Fragmentation of a river ecosystem could alter migration patterns among fish populations (Horváth and Municio, 1998; Jager et al., 2001), producing genetic stocks that are reproductively isolated units and are genetically different from other stocks (Booke, 1999). Stocks are best defined with genotypic or phenotypic markers that are stable and repeatable (Booke, 1999) and identification of discrete populations within stocks is critical for the development of reasonable resource exploitation practices and fishery management (Salini et al., 2004).

Siah-Mahi, Capoeta capoeta gracilis (Keyserling, 1861), one of the subspecies of the genus Capoeta, is an omnivorous, potamodromous cyprinid fish that is found in both lotic and lentic habitats (Samaee et al., 2006, 2009). This species is distributed throughout the freshwater river systems of the southern Caspian Sea basin (Abdoli et al., 2008; Samaee et al., 2009). In addition to its ecological significance, Siah-Mahi is an important species for sport and inland water fishing (Samaee et al., 2009). In the southern Caspian Sea, Siah-Mahi mainly exists in the Tajan River, which is a significant river in this region with a flow of $19.4 \mathrm{~m}^{3} / \mathrm{s}$ (Nazariha and Alinezhad, 1999). In the mid-1990s, the Shahid-Rajaee reservoir dam, which lacks a fishway, was constructed on this river (AnvariFar et al., 2011). This is a major dam according to the classification of McAllister et al. (2001). Because of this construction, the river was fragmented into 2 parts.

In ichthyo-taxonomical studies, morphometric characters are helpful for separating closely related genera, species, and even populations. However, they are not always suitable for identifying closely related species. Hence, the development of molecular techniques has received considerable attention for investigating the genetic diversity and differentiation of fishes (Dhinakaran et al., 2011). A number of different techniques are available for identifying genetic differences between organisms.

The random amplified polymorphic DNA (RAPD) technique involves amplification of target DNA by PCR using arbitrary primers (Rahman et al., 2009). The development of 
RAPD markers allows the examination of genome variation without a priori knowledge of DNA sequences (Welsh and McClelland, 1990). This method had been used to detect genetic diversity within and among strains, species and subspecies, and to assess genome variability (Silva et al., 2008). Our present study had the following objectives: to i) evaluate patterns of genetic variation in the primary range of the species by examining banding patterns using RAPD-PCR techniques; ii) investigate the impact of dam construction on the Tajan River on possible differences between up- and downstream groups of C. c. gracilis using analysis of morphometric characters and the RAPD markers; iii) associate the genetic results with morphometric data using association analysis.

\section{MATERIAL AND METHODS}

\section{Sampling}

A total of 66 C. c. gracilis individuals from 2 sampling sites, up- $\left(36^{\circ} 11^{\prime} 24.91 " \mathrm{~N}\right.$,

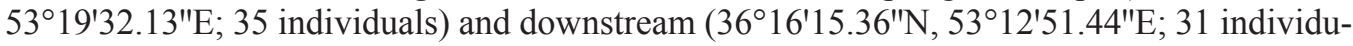
als) of the Shahid-Rajaei dam on the Tajan River (Figure 1) were collected in 2009 by electroshocking with 200-300 V. To preserve tissue for molecular studies, pectoral and pelvic fins from one side of each specimen were cut and preserved in 96\% ethanol, and the alcohol was replaced after 24 and $48 \mathrm{~h}$. For morphological analysis, the sampled fish were fixed in 10\% formaldehyde and sent to the fishery laboratory of the Department of Fisheries and Environmental Science, at the University of Tehran, where measurements of length and weight of the fishes were taken. The sex of the specimens was determined by macroscopic examination of the gonads, and these tissues were used to test for sexual dimorphism in morphometric characters of C. c. gracilis by analysis of variance (ANOVA).

\section{Genetic analysis}

\section{DNA extraction}

DNA was extracted using a Chelex protocol with slight modifications (Walsh et al., 1991). Fin tissue squares, measuring $2 \times 2 \mathrm{~mm}^{2}$, were placed into 1.5-mL Eppendorf tubes containing $500 \mathrm{~mL} \mathrm{10 \%}$ Chelex 100 and $15 \mathrm{~mL} 100 \mathrm{U} / \mathrm{mL}$ proteinase $\mathrm{K}$. The tubes were incubated at $56^{\circ} \mathrm{C}$ for 60 min using a shaker and were then boiled in a water bath for $15 \mathrm{~min}$. The tubes were then centrifuged at $6000 \mathrm{rpm}$ for $10-15 \mathrm{~s}$. The amount and quality of the DNA was evaluated by comparison with known amounts of $\lambda$ DNA after electrophoresis on $0.8 \%$ agarose gels ( $0.32 \mathrm{~g}$ agarose in $40 \mathrm{~mL} 1 \mathrm{X}$ TAE buffer) and spectrophotometric analysis.

\section{PCR primers}

Ten random 10-mer primers were used to initiate PCR amplification in 5 individuals from each of the 2 locations. Six primers (OPB-01, OPB-08, OPB-10, OPB-11, OPB-12, and OPB-17), that consistently and repeatedly amplified polymorphisms within individual fish and produced good resolution of amplified fragment patterns without smearing, were selected and used in the final analysis for all samples from the 2 sites ( 35 up- and 31 downstream individuals). 

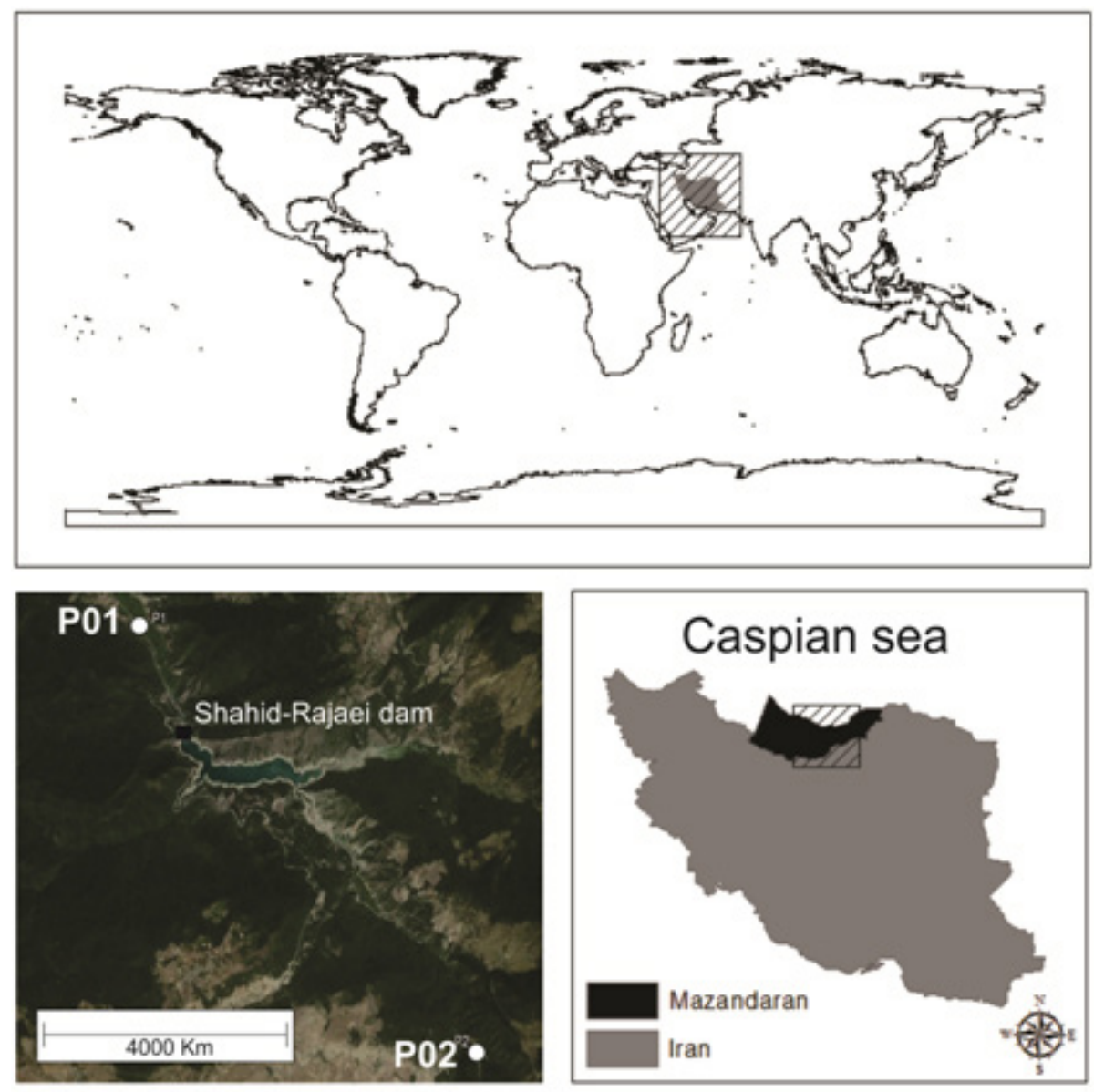

Figure 1. Location of sampling sites including up- and downstream of Shahid Rajaei dam on Tajan River.

\section{PCR amplification}

PCR amplification of the extracted DNA was performed in a $25-\mu \mathrm{L}$ reaction containing $2.5 \mu \mathrm{L}$ 10X PCR buffer ( $500 \mathrm{mM} \mathrm{KCl}$ and $200 \mathrm{mM}$ Tris- $\mathrm{HCl}, \mathrm{pH} 8.4$ ), $2.5 \mathrm{mM} \mathrm{MgCl}, 2.5$ U Taq DNA polymerase, $10 \mathrm{mM}$ of each primer, $150 \mu \mathrm{M}$ of each dNTP, 20 ng genomic DNA, and varying amounts of water. PCR conditions were as follows: $95^{\circ} \mathrm{C}$ for $7 \mathrm{~min}$, followed by 40 cycles of $95^{\circ} \mathrm{C}$ for $1 \mathrm{~min}, 40^{\circ} \mathrm{C}$ for $1 \mathrm{~min}$, and $72^{\circ} \mathrm{C}$ for $1 \mathrm{~min}$, with a final extension for 7 min at $72^{\circ} \mathrm{C}$. A negative control, consisting of all the reaction components except the template DNA, was also included in each amplification.

\section{Gel electrophoresis and band patterns}

Five microliters of the amplification products was mixed with $1 \mu \mathrm{L}$ sample loading buffer and run at $15 \mathrm{~V} / \mathrm{cm}$ for $40 \mathrm{~min}$ on a $1.5 \%$ agarose gel. The gel was visualized by ul- 
traviolet trans-illumination after staining with ethidium bromide. A 100-bp DNA ladder was used as the size reference. Randomly selected sets of DNA template were periodically used as replicates to verify RAPD banding patterns across genotypes and primers. The presence or absence of bands was scored visually. Consistent sharp and reproducible bands were selected for scoring, while bands that were faint or not reproducible over different amplifications were not considered for scoring. All the bands scored in the present study were confirmed by at least 3 separate experiments.

\section{Morphometric measurements}

Twenty-eight traditional morphometric characters were measured using electronic digital calipers to the nearest $0.001 \mathrm{~mm}$. Morphometric parameters investigated in this study were selected based on studies of Holcik et al. (1989), Coad (2008), and Samaee et al. (2009). The same individual took all measurements.

\section{Data analysis}

\section{Morphological data}

As variation should be attributable to body shape differences and not be related to the relative size of the fish, an allometric method (Elliott et al., 1995) was used to remove sizedependent variation in morphometric characters:

$$
\mathrm{M}_{\mathrm{adj}}=\mathrm{M}\left(\mathrm{Ls} / \mathrm{L}_{0}\right)^{\mathrm{b}}
$$

where $M$ is the original raw measurement, $M_{a d j}$ is the size-adjusted measurement, $L_{0}$ is the standard length of the fish, $L s$ is the overall mean of standard length for all fish from all samples in each analysis, and $b$ is estimated for each character as the slope of the regression line of log $\mathrm{M}$ on $\log \mathrm{L}_{0}$ using all fish in each group.

The results obtained from the allometric adjustment were confirmed by testing the significance of the correlation between the transformed variables and standard length. ANOVA was performed for each morphometric character (Zar, 1984). All morphometric characters were then used for standard discriminant function analyses (DFA) and principal component analysis (PCA). The resulting discriminant function was used to calculate the percentage of correctly classified (PCC) fish. A cross-validation using PCC was performed to estimate the expected actual error rates of the classification functions. Statistical analyses for morphometric data were performed using the SPSS software package, version 11.5.

\section{Genetic data}

To analyze the molecular data, RAPD bands were scored manually in binary form, using 1 to indicate the presence and 0 to indicate the absence of a band. Statistical analyses were performed using POPGEN (Yeh et al., 1999) and the Numerical Taxonomy and Multivariate Analysis System (NTSYS-pc version 2.02) (Rohlf, 1989). Genetic differentiation among the samples was examined by multivariate analysis. We also used the principal coordinate analysis ( $\mathrm{PCoA}$ ) method based on a 
distance matrix to visualize the relationship between individuals of the 2 groups more quantitatively. In addition, a possible correlation between morphological differentiation and genetic distance was investigated. The significance of matrix relationships was assessed with the Mantel test (Mantel, 1967) using the NTSYSpc software (Rohlf, 1989). The confidence of the obtained $t$-statistic was evaluated with 1000 random permutations. Prior to testing, the matrices were normalized.

\section{Association analysis}

The association analysis between the morphometric data and genetic data from the 2 studied areas was conducted using a stepwise multiple regression (linear regression) (Roy et al., 2006). Thus, each value of an individual's phenotypic trait was considered a dependent variable $(\mathrm{Y})$, and all RAPD markers were considered independent variables (X). Multiple regression analysis was conducted using the SPSS software package, version 11.5 (Roy et al., 2006).

\section{RESULTS}

\section{Morphological characters}

The age of C. c. gracilis animals in up- and downstream populations of the ShahidRajaei dam ranged from 1 to $>3$ years, indicating that at least 6 generations may have progressed since the construction of the dam. Approximately $70 \%$ of samples in the up- and downstream populations were $>2$ years old. The mean variation between the populations in length and weight, and for all evaluated morphometric measurements is shown in Figures 2 and 3, respectively.

There was no significant correlation between any transformed morphometric variable and standard length $(\mathrm{P}>0.05)$, indicating that the size effect was accounted for in our analysis. Significant differences $(\mathrm{P}<0.05)$ between the Siah-Mahi populations up- and downstream of the Shahid-Rajaei dam on the Tajan River were observed for 16 of 28 morphometric characters (Table 1), and these 16 traits were used further for multivariate analyses. The morphometric characters between the 2 sexes did not differ significantly $(P>0.05)$ (Table 2); hence, the data for both sexes were pooled for all subsequent analyses.

To determine which morphometric measurement most effectively differentiated populations, the contributions of all variables to principal components (PC) were examined. PCA of the 16 morphometric characters showed that PC1 and PC2 accounted for 35.36 and $14.40 \%$ of the variation, respectively. The most significant influences on PC1 were due to body depth, minimum body depth (h), inter-orbital distance, predorsal distance, postdorsal distance, dorsal fin length, height of dorsal fin (hD), length of dorsal fin base, height of anal fin (hA), ventral fin length, and pectoral fin length, while those most contributing to PC2 were head high, postanal length, mandible length (Manl), predorsal distance, and ventral fin length.

Visual examination of plotted PC1 scores for each sample (Figure 4) revealed that the 2 samples of Siah-Mahi, up- and downstream, were clearly distinct. Wilks' lambda tests of the DFA indicated significant differences in the morphometric characters of the 2 populations (Wilks' lambda $=0.227$, chi-squared $=91.155$, and d.f. $=5$ ). In this test, one function was highly significant $(\mathrm{P} \leq 0.01)$. For the discriminant analysis, the average PCC was $98.5 \%$ for morphometric characters. High classification success rates were obtained for the down- (100\%) and upstream (97.14\%) stocks, indicating a high level of correct classification 
of individuals into their original populations. The cross-validation testing procedure correctly classified, on average, $93.9 \%$ of the specimens by using morphometric characters. The measurements that were used in this analysis included body depth, caudal peduncle length (Lpc), Manl, hD, and hA.

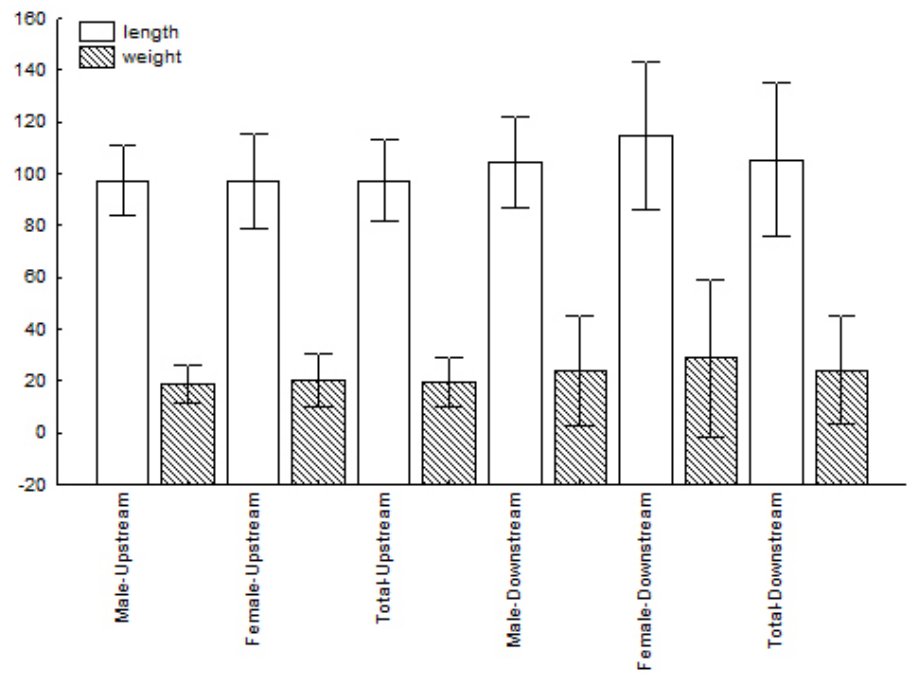

Figure 2. Variation in mean length and weight (mass) from two samples of Capoeta capoeta gracilis, up- and downstream the Tajan River $(\mathrm{P}>0.05)$.

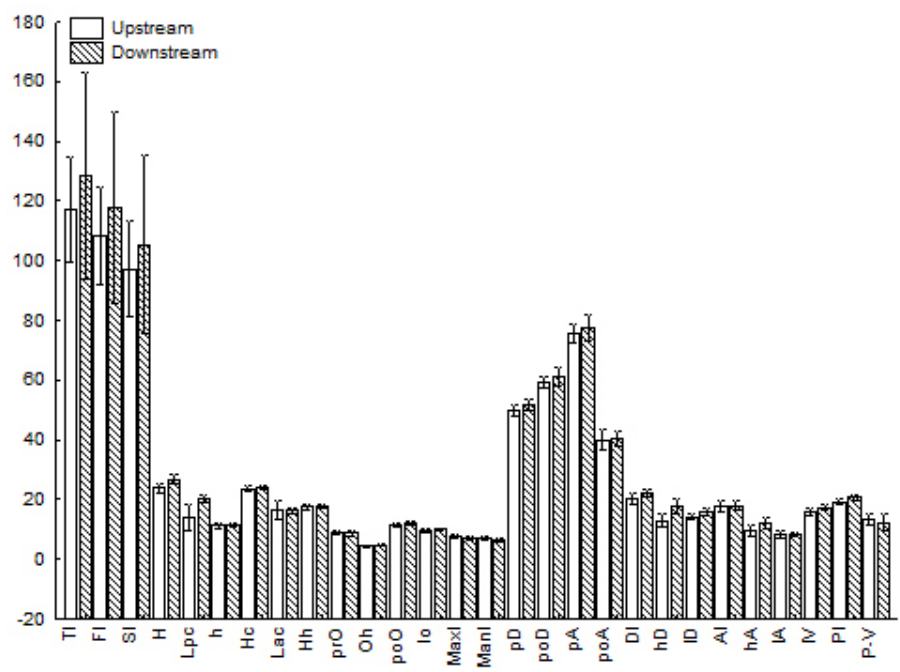

Figure 3. Morphometric differences between the two samples of Capoeta capoeta gracilis, up- and downstream the Tajan River. $\mathrm{Tl}=$ total length; $\mathrm{Fl}=$ fork length; $\mathrm{Sl}=$ standard length; $\mathrm{H}=$ body depth; $\mathrm{Lpc}=$ caudal peduncle length; $\mathrm{h}=$ minimum body depth; $\mathrm{Hc}=$ head length; $\mathrm{Lac}=$ head width; $\mathrm{Hh}=$ head high; $p r O=$ preorbital length (=snout length); $\mathrm{Oh}=$ eye diameter; $\mathrm{poO}=$ postanal length; $\mathrm{Io}=$ inter-orbital distance; $\mathrm{Maxl}=$ maxilla length; $\mathrm{Manl}=$ mandible length; $\mathrm{pD}=$ predorsal distance; $\mathrm{poD}=$ postdorsal distance; $\mathrm{pA}=$ preanal distance; $\mathrm{po} \mathrm{A}=$ postanal length; $\mathrm{Dl}=$ dorsal fin length; $\mathrm{hD}=$ height of dorsal fin; $\mathrm{ID}=$ length of dorsal fin base; $\mathrm{Al}=$ anal fin length; $\mathrm{hA}=$ height of anal fin; $1 \mathrm{~A}=$ length of anal fin base; $1 \mathrm{~V}=$ ventral fin length; $\mathrm{Pl}=$ pectoral fin length; $\mathrm{P}-\mathrm{V}=$ pectoral pelvic length. 
Table 1. Association analysis of morphometric variables and molecular results using stepwise regression, $\mathrm{P} \leq$ 0.05 , with a Bonferroni's correction.

\begin{tabular}{lccc}
\hline Parameters & Number of marker $(\mathrm{T})$ & $\mathrm{R}^{2}(\%) \max$ & $\mathrm{R}^{2}(\%) \mathrm{T}$ \\
\hline $\mathrm{hD}$ & 29 & 31.1 & 93.8 \\
$\mathrm{hA}$ & 21 & 15.9 & 72.1 \\
$\mathrm{lD}$ & 14 & 18.5 & 71.9 \\
$\mathrm{Oh}$ & 11 & 13.5 & 54.1 \\
$\mathrm{H}$ & 11 & 13.0 & 57.6 \\
$\mathrm{Hc}$ & 7 & 28.5 & 59.9 \\
$\mathrm{Lpc}$ & 6 & 20.1 & 55.9 \\
$\mathrm{lV}$ & 4 & 23.2 & 37.3 \\
$\mathrm{Pl}$ & 4 & 17.7 & 40.3 \\
poO & 4 & 12.7 & 36.7 \\
$\mathrm{Io}$ & 3 & 9.4 & 24.5 \\
$\mathrm{pD}$ & 3 & 14.2 & 26.5 \\
poD & 3 & 10.7 & 21.1 \\
$\mathrm{Dl}$ & 3 & 12.8 & 26.0 \\
Manl & 3 & 13.5 & 13.5 \\
\hline
\end{tabular}

$\mathrm{T}=$ number of informative markers for morphometric variables; $\mathrm{R}^{2}(\%) \max =$ maximum of adjusted $\mathrm{R}^{2}$ for each informative marker in morphometric variables or maximum variation of a trait explained by a marker out of total significantly associated markers; $\mathrm{R}^{2}(\%) \mathrm{T}=$ total of adjusted $\mathrm{R}^{2}$ for informative markers in all morphometric variables or total number of markers showing significant association with the trait. For parameter abbreviations, see legend to Figure 3.

Table 2. Results of ANOVA for morphometric traits and sex dimorphism of Capoeta capoeta gracilis up- and downstream of the Shahid-Rajaei dam on the Tajan River.

\begin{tabular}{|c|c|c|c|c|c|c|c|c|}
\hline \multicolumn{6}{|c|}{ Results of ANOVA between locations } & \multicolumn{3}{|c|}{ Results of ANOVA between sexes } \\
\hline Parameters & F value & $\mathrm{P}$ value & Parameters & F value & $P$ value & Parameters & F value & P value \\
\hline $\mathrm{Tl}$ & 2.660 & 0.108 & poD & 8.306 & 0.005 & $\mathrm{H}$ & 8.550 & 0.057 \\
\hline F1 & 2.389 & 0.127 & $\mathrm{pA}$ & 2.720 & 0.104 & Lpc & 15.069 & 0.477 \\
\hline S1 & 2.006 & 0.162 & poA & 0.661 & 0.419 & $\mathrm{H}$ & 0.050 & 0.241 \\
\hline $\mathrm{H}$ & 57.273 & 0.000 & D1 & 14.045 & 0.000 & $\mathrm{Hh}$ & 2.369 & 0.646 \\
\hline Lpc & 64.345 & 0.000 & $\mathrm{hD}$ & 68.578 & 0.000 & $\mathrm{Oh}$ & 7.274 & 0.519 \\
\hline h & 5.390 & 0.023 & ID & 36.808 & 0.000 & poO & 1.605 & 0.425 \\
\hline $\mathrm{Hc}$ & 2.079 & 0.154 & $\mathrm{Al}$ & 0.001 & 0.975 & Io & 0.246 & 0.649 \\
\hline Lac & 0.040 & 0.843 & $\mathrm{hA}$ & 30.480 & 0.000 & Manl & 14.504 & 0.401 \\
\hline $\mathrm{Hh}$ & 4.581 & 0.036 & $1 \mathrm{~A}$ & 0.095 & 0.759 & $\mathrm{pD}$ & 0.012 & 0.100 \\
\hline prO & 0.138 & 0.711 & IV & 30.989 & 0.000 & poD & 3.684 & 0.144 \\
\hline $\mathrm{Oh}$ & 7.751 & 0.007 & P1 & 22.395 & 0.000 & Dl & 4.582 & 0.647 \\
\hline poO & 5.433 & 0.023 & $\mathrm{P}-\mathrm{V}$ & 2.623 & 0.110 & $\mathrm{hD}$ & 12.250 & 0.309 \\
\hline Io & 4.031 & 0.049 & & & & 1D & 14.663 & 0.575 \\
\hline Maxl & 0.967 & 0.329 & & & & $\mathrm{hA}$ & 7.276 & 0.967 \\
\hline Manl & 9.586 & 0.003 & & & & $1 \mathrm{~V}$ & 5.535 & 0.068 \\
\hline $\mathrm{pD}$ & 13.459 & 0.000 & & & & Pl & 1.829 & 0.368 \\
\hline
\end{tabular}

For parameter abbreviations, see legend to Figure 3.

\section{Molecular differentiation}

Six informative primers produced 89 polymorphic bands with $95 \%$ polymorphism. The primer sequences and the number of polymorphic bands obtained from each primer are shown in Table 3. Numbers of scorable fragments varied from 1 to 16, with a size range of 50 to $1100 \mathrm{bp}$. The Mantel test (Mantel, 1967) was used to determine the correlation between genetic and morphometric differentiation. Results of this analysis showed that genetic distances were highly correlated with morphological distances (Mantel's $r=0.742, \mathrm{P}=0.0012$ ). The 
results of genetic variation for all polymorphic bands, including the percentage of polymorphism, observed and effective number of alleles (Nei, 1973), Nei's (1973) gene diversity, and Shannon's information index (Lewontin, 1972) in the upstream population were 94.38, 1.94, $1.59,0.34$, and 0.51 , respectively, and in the downstream population were $95.51,1.95,1.69$, 0.38 , and 0.55 , respectively. Estimates of Nei's (1978) unbiased genetic distance, including average heterozygosity of the total population, average heterozygosity among subpopulations, coefficient of gene differentiation $\left(G_{\mathrm{ST}}\right)$, and gene flow $\left[N_{\mathrm{m}}\right.$; estimated from $G_{\mathrm{ST}}$ as $N_{\mathrm{m}}=0.5$ $\left.\left.\left(1-G_{\mathrm{ST}}\right) / G_{\mathrm{ST}}\right)\right]$ were $0.38,0.36,0.067$, and 6.84 , respectively.

A

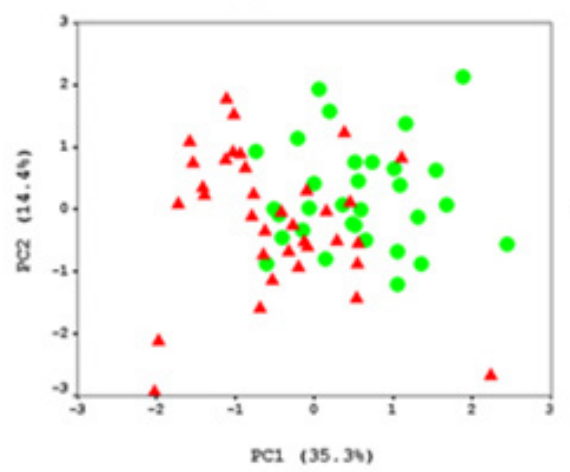

B

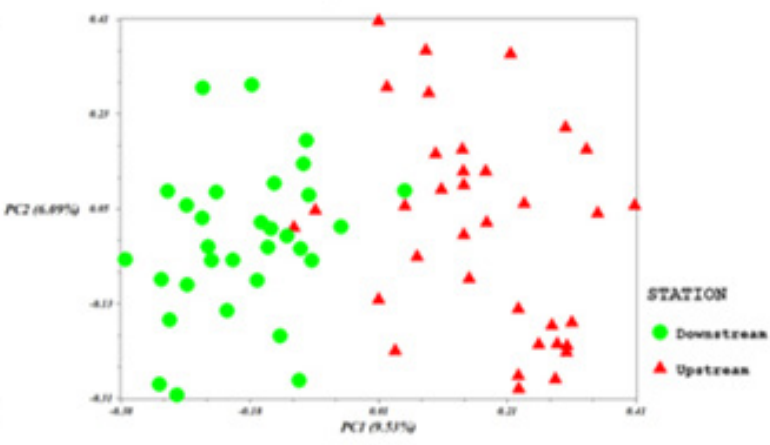

Figure 4. A. Plot of factor scores for principal components, PC1 and PC2, of all morphometric characteristics. B. Principal coordinate analysis (PCoA) 2-D plot of Eigenvectors between specimens from 2 samples of Capoeta capoeta gracilis constructed based on the Jaccard similarity coefficients for RAPD marker data.

Table 3. Sequences of 6 primers used for RAPD analysis and number of polymorphic bands amplified by each in samples of Capoeta capoeta gracilis.

\begin{tabular}{llcc}
\hline Number of polymorphic bands & Primer sequence (5'-3') & G + C $\%$ & Name of primer \\
\hline 16 & 5'-GTTTCGCTCC-3' & 60 & OPB-01 \\
15 & 5'-GTCCACACGG-3' & 70 & OPB-08 \\
14 & 5'-CTGCTGGGAC-3' & 70 & OPB-10 \\
15 & 5'-GTAGACCCGT-3' & 60 & OPB-11 \\
14 & 5'-CCTTGACGCA-3' & 60 & OPB-12 \\
15 & 5'-AGGGAACGAG-3' & 60 & OPB-17 \\
89 & & & Combined \\
\hline
\end{tabular}

Minimum, maximum, and average genetic distances for the 2 populations of C. c. gracilis up- and downstream of the dam were calculated from the similarity matrix based on Jaccard's coefficient, and were $0.1455,0.7382$, and 0.4872 , respectively. The results from the PCoA of RAPD markers showed that C. c. gracilis were separated into 2 main groups by PCo axis 1 (Figure 4B).

\section{Association analysis}

Correlations between morphological and genetic data based on a stepwise regression analysis are shown in Table 4. The results of this analysis demonstrated that 124 genetic markers, and 63 
of 89 polymorphic bands, were significantly correlated with 16 morphometric characters (Table 4), which were the most important morphometric features that segregated the 2 populations of $C$. c. gracilis in the PCA, DFA, and ANOVA. The results from the association analysis demonstrated that the morphometric characters $\mathrm{hD}, \mathrm{hA}, \mathrm{ID}, \mathrm{Oh}$, and $\mathrm{h}$ were the most highly correlated with the polymorphic markers. The variation explained from all informative markers for all morphometric variables and for each informative marker in $\mathrm{hD}$ (of 329 markers) was 93.8 and $31.1 \%$, respectively. The greatest and the least number of markers were related to $\mathrm{hD}$ and Manl, respectively.

\begin{tabular}{|c|c|c|c|c|c|}
\hline Parameters & Source of variance & d.f. & RAPDmax & d.f. & RAPDcom \\
\hline \multirow[t]{2}{*}{$\mathrm{hD}$} & Regression (X) & 1 & $236.91 * * *$ & 25 & $28.31^{* * *}$ \\
\hline & Residual $(\mathrm{Y})$ & 64 & 7.80 & 40 & 0.703 \\
\hline \multirow[t]{2}{*}{ hA } & $\mathrm{X}$ & 1 & $62.65 * * *$ & 13 & $21.83^{* * *}$ \\
\hline & $\mathrm{Y}$ & 64 & 4.73 & 52 & 1.56 \\
\hline \multirow[t]{2}{*}{$1 \mathrm{D}$} & $\mathrm{X}$ & 1 & $22.20 * * *$ & 12 & $7.21 * * *$ \\
\hline & $\mathrm{Y}$ & 64 & 1.40 & 53 & 0.486 \\
\hline \multirow[t]{2}{*}{$\mathrm{Oh}$} & $\mathrm{X}$ & 1 & $1.15^{* * *}$ & 9 & $0.524 * * *$ \\
\hline & $\mathrm{Y}$ & 64 & 0.104 & 56 & 0 \\
\hline \multirow[t]{2}{*}{$\mathrm{H}$} & $\mathrm{X}$ & 1 & $5.48 * *$ & 9 & $2.69^{* * *}$ \\
\hline & $\mathrm{Y}$ & 64 & 0.511 & 56 & 0.249 \\
\hline \multirow[t]{2}{*}{$\mathrm{h}$} & $\mathrm{X}$ & 1 & $88.23 * * *$ & 7 & $27.31^{* * *}$ \\
\hline & $\mathrm{Y}$ & 64 & 3.27 & 58 & 1.83 \\
\hline \multirow[t]{2}{*}{ Lpc } & $\mathrm{X}$ & 1 & $295.7^{* * *}$ & 6 & $138.2 * * *$ \\
\hline & $\mathrm{Y}$ & 64 & 17.0 & 59 & 9.39 \\
\hline \multirow[t]{2}{*}{$1 \mathrm{~V}$} & $\mathrm{X}$ & 1 & $23.56^{* * *}$ & 4 & $10.08^{* * *}$ \\
\hline & $\mathrm{Y}$ & 64 & 1.14 & 61 & 0.925 \\
\hline \multirow[t]{2}{*}{$\mathrm{Pl}$} & $\mathrm{X}$ & 1 & $21.49 * * *$ & 4 & $12.47^{* * * *}$ \\
\hline & $\mathrm{Y}$ & 64 & 1.43 & 61 & 1.04 \\
\hline \multirow[t]{2}{*}{ poO } & $\mathrm{X}$ & 1 & $4.58^{* *}$ & 4 & $3.31^{* * *}$ \\
\hline & $\mathrm{Y}$ & 64 & 0.438 & 61 & 0.318 \\
\hline \multirow[t]{2}{*}{$\mathrm{Hh}$} & $\mathrm{X}$ & 1 & $5.68 * *$ & 3 & $4.72^{* * *}$ \\
\hline & $\mathrm{Y}$ & 64 & 0.644 & 62 & 0.528 \\
\hline \multirow[t]{2}{*}{ Io } & $\mathrm{X}$ & 1 & $2.25^{*}$ & 3 & $1.94 * * *$ \\
\hline & $\mathrm{Y}$ & 64 & 0.291 & 62 & 0.242 \\
\hline \multirow{2}{*}{$\mathrm{pD}$} & $\mathrm{X}$ & 1 & $38.99 * * *$ & 3 & $25.33^{* * * *}$ \\
\hline & $\mathrm{Y}$ & 64 & 3.31 & 62 & 2.82 \\
\hline \multirow[t]{2}{*}{ poD } & $\mathrm{X}$ & 1 & $61.23 * * *$ & 3 & $41.82 * * *$ \\
\hline & $\mathrm{Y}$ & 64 & 6.96 & 62 & 6.15 \\
\hline \multirow[t]{2}{*}{$\mathrm{Dl}$} & $\mathrm{X}$ & 1 & $29.07 * *$ & 3 & $20.21 * * *$ \\
\hline & $\mathrm{Y}$ & 64 & 2.76 & 62 & 2.34 \\
\hline \multirow[t]{2}{*}{ Manl } & $\mathrm{X}$ & 1 & $4.87 * * *$ & 1 & $4.87^{* * *}$ \\
\hline & Y & 64 & 0.437 & 64 & 0.437 \\
\hline
\end{tabular}

$* * * \mathrm{P} \leq 0.01 ; * * \mathrm{P} \leq 0.05 ; * \mathrm{P}>0.05$. RAPDmax $=$ mean square of one polymorphic band (Predictor). RAPDcom $=$ mean square of all polymorphic bands (Predictors). For parameter abbreviations, see legend to Figure 3.

Significant associations were observed for 63 of the 89 polymorphic markers with at least one of the 16 traits, with the number of markers associated with individual traits ranging from 1 to 25 . Among these 16 traits, Manl was significantly related to only one RAPD marker, whereas $\mathrm{hD}$ was significantly related to $25 \mathrm{RAPD}$ markers. These associated markers explained $100 \%$ of the variation in the 16 phenotypic traits examined.

\section{DISCUSSION}

The results of this study demonstrate that the construction of the Shahid-Rajaei dam on 
the Tajan River effectively created 2 genetically and morphologically different populations of C. $c$. gracilis up- and downstream of this dam. Examination of 28 morphometric characteristics between the 2 classified groups revealed that individuals from downstream sites were generally larger than individuals inhabiting the upstream area (except with respect to Lac, prO, Maxl, Manl, Al, 1A, and $\mathrm{P}-\mathrm{V})$. The results obtained from ANOVA demonstrated high phenotypic variation between these 2 populations. This segregation was confirmed by another multivariate analysis, PCA.

Examination of the morphometric characteristics along PCA axes revealed that the observed differences between the 2 groups were not related to a particular part of the fish body. Instead, the differentiation was due to a series of differences related to different parts of the fish body. These findings agree with observations of C. c. gracilis populations in the Shirrud and Tajan Rivers in the southern Caspian Sea basin (Samaee et al., 2009; AnvariFar et al., 2011). The morphological differences observed were related only to body shape variation and not to size effects, which were successfully accounted for by allometric transformation. Size may play a predominant role in biasing morphometric analyses, and thus result in erroneous data if it cannot be removed in statistical analyses (Tzeng, 2004). In the present study, the size effect was removed successfully by allometric transformation, and therefore, any significant differences observed represented body shape variation as tested using ANOVA and multivariate analysis.

$\mathrm{hD}, \mathrm{hA}, \mathrm{ID}, \mathrm{Oh}$, and $\mathrm{h}$ were revealed to be important population-differentiating traits in the DFA and the PCA. In total, 89 DNA markers were evaluated for associations with at least 1 of the 16 morphological traits; 63 DNA markers exhibited association, each with at least 1 of the 16 traits. In addition, the Mantel test revealed a significant correlation between genetic distance and morphological distance. In this study, the average genetic distances for 2 populations that were calculated from the similarity matrix based on Jaccard's coefficient was 0.49 . Considering that the standard value for population differentiation is 0.5 (Gharaei et al., 2005), our data suggest that these 2 populations are segregated to a high degree. An $N_{\mathrm{m}} \leq 1.0$ (fewer than one migrant per generation into a population), and a value of $G_{\mathrm{ST}}>0.25$, are generally regarded as threshold quantities beyond which significant population differentiation occurs (Slatkin, 1987). The value of $N_{\mathrm{m}}$ (average of individuals migrating among populations in each generation) and $G_{\mathrm{ST}}$ in this study were high and low, respectively, indicating the presence of genetic exchange. Therefore, this $N_{\mathrm{m}}$ must have occurred before the 2 populations were segregated (i.e., before dam construction). A comparison of $\mathrm{H}$ and I between the 2 populations demonstrated that the diversity in the downstream population was greater than that in the upstream population, and that this was most likely due to changed conditions in the downstream region due to the dam. The combination of the 2 forces creates a powerful mechanism for maintaining within-species diversity (Buckler and Thornsberry, 2002). Furthermore, Hernandez-Martich and Smith (1997) demonstrated that genetic drift and selection are both significant factors causing local differentiation and the up-/downstream dichotomy in genetic characteristics.

The causes of morphological differences between populations are often quite difficult to explain (Poulet et al., 2004; Silva et al., 2008). It has been suggested that the morphological characteristics of fishes are determined by an interaction between genetic and environmental factors (Swain and Foote, 1999; Poulet et al., 2004; Salini et al., 2004; Pinheiro et al., 2005; AnvariFar et al., 2011). The environmental characteristics prevailing during early stages of development, when individuals are more phenotypically influenced by the environment, are of particular importance (Pinheiro et al., 2005). The influences of environmental parameters on morphometric characters have been thoroughly discussed by 
several authors in the course of fish population segregation studies (e.g., Swain and Foote, 1999; Marcil et al., 2006).

Dams can change the feeding habits, food availability, growth patterns, and reproductive strategies of particular species living up- and downstream of it. The importance of such factors on producing morphological differentiation in fish species is well known (Akbarzadeh et al., 2009). For example, different environmental and habitat conditions, such as temperature, turbidity, food availability, water depth, and flow, in different rivers have been shown to cause differentiation in Capoeta sp (Samaee et al., 2009; AnvariFar et al., 2011). Construction of a dam on a river can affect migratory movements of species into and out of the upstream area. The blockage of fish movements upstream can have a very significant impact on fish stocks. For example, genetic exchange with downstream segments is reduced or prevented (McAllister et al., 2001). In addition, the construction of a dam can lead to dramatic changes in the environment of a river and particularly affect fish communities (Craig, 2000). Therefore, the distinctive environmental conditions of the up- and downstream locations may be the cause of morphological differentiation between these 2 sites.

Phenotypic variability may not necessarily reflect population differentiation at the molecular level (Silva et al., 2008). Thus, we supplemented our morphological results with those obtained by the RAPD technique. The outcome of the multivariate analysis of RAPD data was largely congruent with the morphological results. The remarkable congruence between the molecular and morphological results reported here establishes that the morphological differences between populations have a genetic basis and are not solely due to environmental influences (Samaee et al., 2006). Such discrimination has previously been demonstrated among 6 populations of C. c. gracilis located in the Aras, Sefidrud, Shirud, Tonekabon, Haraz, and Gorganrud River systems in Iran (Samaee et al., 2006). In this study, all the measures of genetic variation (percentage of polymorphism, observed and effective number of alleles, gene diversity, and Shannon's information index) within populations were consistently higher in the down- than in the upstream populations. These results are similar to those of Hernandez-Martich and Smith (1997), who showed that a dam affected the genetic structure of Gambusia holbrooki populations. Those authors also stated that genetic drift, $N_{\mathrm{m}}$, and selection could cause the observed geographical patterns in the genetic structure. Since up- and downstream populations of C. c. gracilis are geographically isolated, there is currently no opportunity for gene flow among them. Therefore, they may have diverged from each other through drift and/or differential selection.

In conclusion, the present study provides basic information about the biology and differentiation of C. c. gracilis populations in the upstream and downstream regions of the Tajan River, and it suggests that morphological and genetic variations observed in C. c. gracilis should be considered in fishery management and for the commercial exploitation of this species. Overall, the findings suggest that there are significant morphological and genetic differentiations between C. c. gracilis populations above and below the dam, supporting the hypothesis proposed in the present study. Unfortunately, there are no pre-dam historical samples or any parallel situations nearby in the river in which up- and downstream populations without any barriers could be compared.

Finally, even though RAPD is a dominant marker that does not differentiate between homozygotes and heterozygotes, it provides baseline information on the population structure and suggests that additional studies using mitochondrial and microsatellite markers will further enhance our understanding of the genetic structure of Siah-Mahi populations. 


\section{ACKNOWLEDGMENTS}

We would like to express our sincere thanks to J.A. Khalili, K. Amani, M. Kargar, N. Ghovati, S. Hossein-Zade, F. Azizi, and S. Pishnamaz-Zade for their help in specimen collection. We also thank the Habib-Alla AnvariFar for financial support. Special thanks to S. Rashidi Monfared for reviewing the manuscript and making suggestions. R.P. Bastos thanks CNPq for his scholarship.

\section{REFERENCES}

Abdoli A, Rasooli P and Mostafavi H (2008). Length-weight relationships of Capoeta capoeta capoeta (Gueldenstaedt, 1772) in the Gorganrud River, south Caspian Basin. J. Appl. Ichthyol. 24: 96-98.

Akbarzadeh A, Farahmand H, Shabani AA, Karami M, et al. (2009). Morphological variation of the pikeperch Sander lucioperca (L.) in the southern Caspian Sea, using a truss system. J. Appl. Ichthyol. 25: 576-582.

AnvariFar H, Khyabani A, Farahmand H, Vatandoust S, et al. (2011). Detection of morphometric differentiation between isolated up- and downstream populations of Siah Mahi (Capoeta capoeta gracilis) (Pisces: Cyprinidae) in the Tajan river (Iran). Hydrobiologia 673: 41-52.

Booke HE (1999). The stock concept revisited: perspectives on its history in fisheries. Fish Res. 43: 9-11.

Buckler ES and Thornsberry JM (2002). Plant molecular diversity and applications to genomics. Curr. Opin. Plant Biol. 5: 107-111.

Coad BW (2008). Freshwater Fishes of Iran. Available at [http://www.briancoad.com]. Accessed August 17, 2011.

Craig JF (2000). Large Dams and Freshwater Fish Biodiversity. Prepared for Thematic Review II.1: Dams, Ecosystem Functions and Environmental Restoration. World Commission on Dams (WCD), Cape Town.

Dhinakaran A, Alikunhi NM, Chinnathambi S, Sornam R, et al. (2011). Assessment of morphometric and genetic variation an three freshwater fish species of the genus (Osteichthyes: Cyprinidae). Not. Sci. Biol. 3: 12-16.

Elliott NG, Haskard K and Koslow JA (1995). Morphometric analysis of orange roughly (Hoplostethus atlanticus) off the continental slope of Southern Australia. J. Fish Biol. 46: 202-220.

Gharaei A, Pourkazemi M, Rezvani S and Mojazi-Amiri B (2005). Genetic difference; and resemblance between Acipenser persicus and Acipenser gueldenstaedtii by means of RAPD technique. Iran. J. Fish. Sci. 14: 91-102.

Haas TC, Blum MJ and Heins DC (2010). Morphological responses of a stream fish to water impoundment. Biol. Lett. 6: 803-806.

Hernandez-Martich JD and Smith MH (1997). Downstream gene flow and genetic structure of Gambusia holbrooki (eastern mosquitofish) populations. Heredity 79: 295-301.

Holcik J, Kinzelbach R, Sokolov LI and Vasil'ev VP (1989). Acipenser sturio Linnaens, 1758. In: The Freshwater Fishes of Europe. Vol. 1 (II) (Holcik J, ed.). Aula-Verlag, Wiesbaden, 367-394.

Horváth E and Municio MAT (1998). Impacts of dams on fish fauna/feasibility of migration measures. 2nd. International $\mathrm{PhD}$ Symposium in Civil Engineering, Budapest.

Jager HI, Chandler JA, Lepla KB and Van Winkle W (2001). A theoretical study of river fragmentation by dams and its effects on white sturgeon populations. Environ. Biol. Fishes 60: 347-361.

Lewontin RC (1972). The apportionment of human diversity. Evol. Biol. 6: 381-398.

Mantel N (1967). The detection of disease clustering and a generalized regression approach. Cancer Res. 27: 209-220.

Marcil J, Swain DP and Hutchings JA (2006). Genetic and environmental components of phenotypic variation in body shape among populations of Atlantic cod (Gadus morhua L). Biol. J. Linn. Soc. 88: 351-365.

McAllister DE, Craig JF, Davidson N, Delany S, et al. (2001). Biodiversity Impacts of Large Dams. Background Paper Nr. 1. Prepared for IUCN / UNEP / WCD.

Nazariha M and Alinezhad S (1999). Planning for improvement and decrease negative impacts of Shahid-Rajaei dam. Environ. Biol. 30: 9-18.

Nei M (1973). Analysis of gene diversity in subdivided populations. Proc. Natl. Acad. Sci. U. S. A. 70: 3321-3323.

Nei M (1978). Estimation of average heterozygosity and genetic distance from a small number of individuals. Genetics 89: 583-590.

Pinheiro A, Teixeira CM, Rego AL, Marques JF, et al. (2005). Genetic and morphological variation of Solea lascaris (Risso, 1810) along the Portuguese coast. Fish Res. 73: 67-78.

Poulet N, Berrebi P, Crivelli AJ, Lek S, et al. (2004). Genetic and morphometric variations in the pikeperch (Sander lucioperca L.) of a fragmented delta. Arch. Hydrobiol. 159: 531-554. 
Rahman SM, Khan MR, Islam S and Alam S (2009). Genetic variation of wild and hatchery populations of the catla Indian major carp (Catla catla Hamilton 1822: Cypriniformes, Cyprinidae) revealed by RAPD markers. Genet. Mol. Biol. 32: $197-201$.

Rohlf FJ (1988). NTSYSpc: Numerical Taxonomy and Multivariate Analysis System. Exeter, New York.

Roy JK, Bandopadhyay R, Rustgi S, Balyan HS, et al. (2006). Association analysis of important agronomic traits using SSR, SAMPL and AFLP markers in bread wheat. Curr. Sci. India 90: 683-689.

Salini JP, Milton DA, Rahman MJ and Hussain MG (2004). Allozyme and morphological variation throughout the geographic range of the tropical shad, hilsa Tenualosa ilisha. Fish. Res. 66: 53-69.

Samaee SM, Mojazi-Amiri B and Hosseini-Mazinani SM (2006). Comparison of Capoeta capoeta gracilis (Cyprinidae, Teleostei) populations in the south Caspian Sea River basin, using morphometric ratios and genetic markers. Folia Zool. 55: 323-335.

Samaee SM, Patzner RA and Mansour N (2009). Morphological differentiation within the population of Siah Mahi, Capoeta capoeta gracilis, (Cyprinidae, Teleostei) in a river of the south Caspian Sea basin: a pilot study. J. Appl. Ichthyol. 25: 583-590.

Silva DM, da Cruz AD, Bastos RP, Telles MPC, et al. (2008). Morphometric and genetic differentiation among populations of Eupemphix nattereri (Amphibia, Anura, Leiuperidae) from central Brazil. Iheringia, Sér. Zool. 98: 493-500.

Slatkin M (1987). Gene flow and the geographic structure of natural populations. Science 236: 787-792.

Swain DP and Foote CJ (1999). Stocks and chameleons: The use of phenotypic variation in stock identification. Fish. Res. 43: 113-128.

Tzeng TD (2004). Morphological variation between populations of spotted mackerel Scomber australacicus of Taiwan. Fish. Res. 68: 45-55.

Walsh PS, Metzger DA and Higuchi R (1991). Chelex 100 as a medium for simple extraction of DNA for PCR-based typing from forensic material. Biotechniques 10: 506-513.

Welsh J and McClelland M (1990). Fingerprinting genomes using PCR with arbitrary primers. Nucleic Acids Res. 18: 7213-7218.

Yeh FC, Yang RC and Boyle T (1999). POPGENE, Version 1.31. Microsoft Window-Based Freeware for Population Genetic Analysis. Available at [http://www.ualberta.ca/ fyeh/fyeh]. Accessed February 10, 2011.

Zar JH (1984). Biostatistical Analysis. Prentice Hall, Inc., Englewood Cliffs. 